\title{
PENGARUH FRAUD TRIANGLE FACTORS TERHADAP PERILAKU
}

FRAUD

\author{
Oleh \\ Taufik Andre Setiyono \\ STIE Bank BPD Jateng
}

\begin{abstract}
The Fraud action is frequent and increase in many area. It brings a loss to firms and government. Many factors can affect Fraud, such as unsuitability of compensation, internal control ineffectiveness, and perceived behavioral control. This research aims to obtain empirical evidence abaout influence of unsuitability of compensation, internal control ineffectiveness, and perceived behavioral control on Fraud with intention to Fraud as an intervening variable.

Population of this research is the civil servant in Tegal city as much as 564. The samples are 155 with purposive sampling technique type quota sample. The data of this research obtained were analyzed by using Partial Least Square (PLS). The data were processed by the SmartPLS3.0. software application.

The result showed that internal control ineffectiveness and perceived behavioral control positive significantly affect to intention to Fraud, internal control ineffectiveness and perceived behavioral control also positive significantly affect to Fraud. But this research showed that unsuitability of compensation not significantly affect to intention to Fraud, and not significantly affect to Fraud. Intention to Fraud not significantly affect to Fraud. Direct effect between unsuitability of compensation, internal control ineffectiveness and perceived behavioral control to Fraud is more than indirect effect. It proves that the intention to Fraud is not the mediator in this research.
\end{abstract}

Keywords : unsuitability of compensation, internal control ineffectiveness, perceived behavioral control, intention to Fraud, Fraud.

\section{PENDAHULUAN}

Sejak diberlakukannya Undang-Undang Nomor 32 Tahun 2004 tentang Pemerintah Daerah, pemerintahan yang mulanya menganut sistem sentralisasi beralih menjadi desentralisasi. Desentralisasi pengelolaan keuangan negara turut menggeser ruang korupsi ke level daerah (Najahningrum, 2013). Dalam Laporan Hasil Pemeriksaan Badan Pemeriksa Keuangan Republik Indonesia (LHP BPK-RI) perwakilah Jawa Tengah, terdapat 3 Pemkot/Pemkab se-Jawa Tengah yang mendapat opini WDP 5 tahun berturut-turut sejak 2012 hingga 2016. Ketiga Pemkot/Pemkab tersebut adalah Kabupaten Brebes, Kabupaten Rembang, dan Kota Tegal. Berikut ini 
temuan kasus beserta jumlah kerugian negara yang terjadi pada Pemkot/Pemkab tersebut dalam kurun waktu 5 tahun terakhir:

Tabel 1

Temuan Kasus dan Jumlah Kerugian Negara

\begin{tabular}{|c|l|c|r|}
\hline No. & \multicolumn{1}{|c|}{ Kabupaten/Kota } & Jumlah Kasus & Jumlah Kerugian Negara \\
\hline 1. & Kota Tegal & 3 & Rp. 38.412.000.000 \\
\hline 2. & Kabupaten Brebes & 4 & Rp. 13.582 .600 .000 \\
\hline 3. & Kabupaten Rembang & 6 & Rp. 6.366.000.000 \\
\hline
\end{tabular}

Sumber: KPK, Kejaksaan, KP2KKN

Berdasarkan tabel tersebut, kerugian Negara terbesar berada di Kota Tegal dengan tiga kasus. Perincian kasus beserta jumlah kerugian Negara adalah sebagai berikut:

1. Tahun 2012-2014, kasus dana hibah KONI Kota Tegal dengan melakukan penyimpangan terkait LPJ fiktif, kegiatan fiktif dan monitoring fiktif sehingga Negara dirugikan senilai 921 juta Rupiah.

2. Tahun 2013, kasus korupsi pekerjaan lanjutan pembangunan asrama dan ruang kelas tahap II pada Badan Pengembangan SDM Kementerian Perhubungan di Kota Tegal yang mengakibatkan kerugian Negara senilai 2,4 miliar Rupiah.

3. Tahun 2015, kasus tukar guling tanah aset daerah antara Pemerintah Kota Tegal dengan pihak swasta yang merugikan Negara senilai 35,1 miliar Rupiah.

Kasus-kasus yang merugikan negara tersebut merupakan bentuk nyata dari tindak korupsi. Menurut Tuanakotta (2014) dalam teori fraud tree, korupsi adalah bentuk fraud yang paling merajalela dan sukar dicegah maupun dideteksi karena erat kaitannya dengan kerjasama yang terencana dan terstruktur dengan pihak-pihak lain.

Fraud dapat memicu seseorang atau kelompok dalam bertindak melanggar hukum untuk mendapatkan keuntungan bagi dirinya sendiri maupun kelompoknya. Terdapat 3 faktor mendasar alasan seseorang berperilaku fraud, yakni pressure, opportunity, dan rationalization (Cressey, 1953).

Fraud bermula dari suatu tekanan yang menghimpit. Pegawai mempunyai kebutuhan keuangan yang mendesak, yang tidak dapat diceritakannya kepada orang lain (Tuanakotta, 2010). Zimbelman et al (2014) menyatakan sebagian besar perilaku fraud dikarenakan adanya tekanan keuangan. Tekanan keuangan dapat timbul karena tidak sesuainya kompensasi yang diterima oleh pegawai. Pegawai seharusnya diberi kompensasi sesuai dengan pendidikan maupun pengabdian kepada instansi atau 
kriteria pemberian kompensasi lainnya. Instansi yang tidak memberikan kompensasi kepada pegawai sesuai dengan kriteria pemberian kompensasi, akan menimbulkan kekecewaan yang mendorong pegawai melakukan perilaku fraud sebagai respon negatif.

Diantara riset mengenai pengaruh kompensasi terhadap fraud yakni, Chandra dan Ikhsan (2015) serta Shintadevi (2015) yang menyimpulkan bahwa kompensasi yang sesuai berpengaruh negatif terhadap perilaku fraud. Sedangkan riset Ahriati dkk (2015) dan Mustika dkk (2016) menunjukkan hasil yang kontras, yaitu bahwa pemberian kompensasi yang sesuai tidak berpengaruh terhadap tingkat perilaku fraud.

Fraud juga didasari oleh kesempatan. Kesempatan merupakan peluang yang dimiliki untuk melakukan fraud, menyembunyikannya, atau menghindari adanya sanksi tegas (Zimbelman et al, 2014). Pengendalian internal yang tidak efektif merupakan salah satu penyebab terjadinya fraud seperti yang termuat dalam LHP BPK-RI. Berdasarkan hasil KMPG Fraud Survey juga ditemukan bahwa fraud terjadi karena tidak efektifnya pengendalian internal (Hidayat dan Nugroho, 2010).

Riset mengenai hubungan pengendalian internal terhadap perilaku fraud diantaranya dilakukan oleh Ahriani dkk (2014), Prawira dkk (2014), dan Putri (2014). Berdasarkan riset-riset tersebut dapat disimpulkan bahwa pengendalian internal yang efektif berpengaruh negatif terhadap perilaku fraud. Sementara riset lainnya yang dilakukan oleh Ahriati dkk (2015), Adi dkk (2016), dan Mustika dkk (2016) menyimpulkan bahwa efektif atau tidaknya pengendalian internal tidak berpengaruh terhadap tingkat perilaku fraud.

Munculnya fraud juga didasari oleh faktor rasionalisasi. Tuanakotta (2014) menjelaskan, rasionalisasi yaitu tindakan mencari pembenaran sebelum melakukan fraud, bukan sesudahnya. Pelaku fraud cenderung mempercayai bahwa tindakannya bukanlah tindakan yang menyalahi aturan. Keyakinan ini didukung oleh adanya keyakinan individu mengenai faktor pendukung dan/atau penghambat untuk melakukan suatu perilaku yang didasarkan pada pengalaman terdahulu maupun informasi yang dimiliki individu. Keyakinan individu ini biasa disebut perceived behavioral control.

Riset mengenai perceived behavioral control terhadap perilaku fraud dilakukan oleh Blanthorne (2000), Bobek dan Hatfield (2003), Cummings et al (2009), serta 
Hidayat dan Nugroho (2010). Riset yang dilakukan oleh Cummings et al (2009) serta Hidayat dan Nugroho (2010) menyimpulkan bahwa perceived behavioral control yang rendah memiliki pengaruh terhadap timbulnya perilaku fraud. Hasil tersebut berbeda dengan riset yang dilakukan oleh Blanthorne (2000) serta Bobek dan Halfield (2003) yang menyatakan bahwa perceived behavioral control tidak memiliki pengaruh terhadap perilaku fraud.

Pada riset-riset terdahulu mengenai perilaku fraud, fraud triangle theory digunakan sebagai kerangka atau teori yang mendasari riset-riset tersebut. Namun dalam kerangka teori yang sama, riset-riset tersebut menunjukkan hasil yang beragam. Pada fraud triangle theory, variabel fraud dipengaruhi oleh pressure, opportunity, and rationalization. Fraud triangle theory tidak memasukkan faktor niat individu pada perilaku fraud, padahal faktor niat memiliki peran penting dalam mempengaruhi perilaku fraud. Individu yang memiliki tekanan, kesempatan, dan alasan rasional tetapi tidak memiliki niat untuk melakukan fraud maka tidak akan melakukan fraud. Hal ini mengindikasikan pentingnya niat dalam memunculkan perilaku fraud. Faktor niat (intention) juga merupakan penentu dari perilaku dalam theory planned behavior. Integrasi fraud triangle theory dan Theory of Planned Behavior dengan memasukkan faktor niat dari Theory of Planned Behavior ke dalam fraud triangle theory sehingga kekurangan dalam fraud triangle theory dapat diatasi. Hal tersebut menunjukkan bahwa fraud triangle theory dan Theory of Planned Behavior dapat digunakan secara bersama-sama untuk menganalisis faktor-faktor yang mempengaruhi perilaku fraud.

Adanya kasus-kasus fraud seperti suap, manipulasi, korupsi, gratifikasi, dan lain sebagainya yang melibatkan pegawai instansi pemerintahan menjadikan akuntabilitas laporan keuangan sektor publik patut dipertanyakan, sehingga menarik untuk dilakukan riset terhadap faktor-faktor pemicu adanya perilaku fraud. Berdasarkan phenomena dan research gap serta uraian latar belakang permasalahan tersebut, maka mendorong peneliti untuk melakukan riset dengan judul "Pengaruh Fraud Triangle

\section{Factors terhadap Perilaku Fraud".}

\section{Rumusan Masalah}

Riset ini berlandaskan adanya phenomena dan research gap dari riset terdahulu. Chandra dan Ikhsan (2015) serta Shintadevi (2015) meneliti pengaruh kompensasi yang sesuai terhadap perilaku fraud. Dari hasil riset bisa diambil kesimpulan berupa 
kompensasi yang sesuai berpengaruh negatif terhadap perilaku fraud. Hasil ini kontras dengan hasil riset Ahriati dkk (2015) dan Mustika dkk (2016) yang menyimpulkan kompensasi yang sesuai yang dialokasikan instansi tidak meminimalkan tingkat fraud. Hal ini diduga karena kompensasi yang diberikan perusahaan tidak sesuai dengan kualifikasi masing-masing pegawai. Selain itu, hasil yang didapat pegawai dari fraud lebih besar dibandingkan dengan kompensasi yang diterima dari instansi.

Hasil riset Ahriani dkk (2014), Prawira dkk (2014), dan Putri (2014) menyimpulkan pengendalian internal yang efektif memiliki pengaruh negatif terhadap perilaku fraud. Sedangkan hasil riset Ahriati dkk (2015), Adi dkk (2016) dan Mustika dkk (2016) memberikan kesimpulan pengendalian internal yang efektif tidak memiliki pengaruh terhadap perilaku fraud. Kondisi tersebut diduga karena sikap dan cara berfikir maupun cara bertindak seorang pegawai dalam suatu instansi cenderung berbeda-beda. Perbedaan tersebut akan menentukan tindakan seorang pegawai dalam menjalankan tugasnya.

Riset yang dilakukan oleh Cummings et al (2009) serta Hidayat dan Nugroho (2010) menunjukkan hasil perceived behavioral control yang rendah memiliki pengaruh terhadap timbulnya perilaku fraud. Hasil tersebut tidak konsisten dengan hasil riset sebelumnya yang dilakukan oleh Blanthorne (2000) serta Bobek dan Hatfield (2003) yang menunjukkan bahwa perceived behavioral control tidak memiliki pengaruh terhadap perilaku fraud. Kondisi ini diduga disebabkan karena perilaku yang ditunjukkan bisa jadi bertentangan dengan apa yang diniatkan individu tersebut. Hal ini diakibatkan oleh kondisi lapangan yang tidak memungkinkan untuk memunculkan perilaku yang diniatkan sehingga dengan cepat mempengaruhi perceived behavioral control individu tersebut.

Berdasarkan uraian diatas, permasalahan yang diangkat dalam riset ini adalah:

1. Apakah ketidak-sesuaian kompensasi berpengaruh positif terhadap perilaku fraud?

2. Apakah ketidak-efektifan pengendalian internal berpengaruh positif terhadap perilaku fraud?

3. Apakah perceived behavioral control berpengaruh positif terhadap perilaku fraud?

\section{Tujuan dan Manfaat Penelitan}

Berdasarkan uraian yang dipaparkan, tujuan riset ini mencakup: 
1. Menganalisis dan menguji secara empiris pengaruh ketidak-sesuaian kompensasi terhadap perilaku fraud.

2. Menganalisis dan menguji secara empiris pengaruh ketidak-efektifan pengendalian internal terhadap perilaku fraud.

3. Menganalisis dan menguji secara empiris pengaruh perceived behavioral control terhadap perilaku fraud.

\section{PAPARAN TEORITIS}

\section{Fraud Triangle Theory}

Fraud triangle theory dikembangkan Cresssey (1953) melalui sebuah risetnya tentang alasan mengapa seseorang melakukan fraud. Fraud Triangle Theory adalah sebuah teori segitiga kecurangan yang menggambarkan tiga kondisi penyebab terjadinya fraud. Kesimpulannya, faktor-faktor tersebut adalah pressure, opportunity, dan rationalization. Tekanan memiliki beberapa pengertian, di antaranya kondisi yang berat saat seseorang menghadapi kesulitan, keadaan dimana seseorang merasa ditekan, pandangan seseorang terhadap kebutuhan yang tidak dapat diceritakannya kepada orang lain, dan lain sebagainya. Kesempatan dapat dipahami sebagai situasi dan kondisi yang ada pada setiap individu. Situasi dan kondisi tersebut memungkinkan seseorang melakukan kegiatan yang memungkinkan terjadinya fraud. Rasionalisasi dapat diartikan sebagai suatu tindakan pembenaran saat pelaku berada didalam suatu keadaan yang tidak diinginkan. Pada umumnya, pelaku menyiapkan pembenaran sebelum melakukan fraud, bukan sesudahnya.

\section{Perilaku Fraud}

Definisi Fraud menurut Tuanakotta (2014) adalah penyerapan konsep hukum ke dalam ilmu akuntansi dan merupakan unsur penting didunia akuntansi forensik. Fraud mengandung unsur kesengajaan, niat jahat, penipuan, penyembunyian, dan penyalahgunaan wewenang serta melanggar hukum. Zimbelman et al (2014) menjelaskan fraud merupakan suatu istilah yang umum dan mencakup segala macam cara yang dapat digunakan dengan kelihaian tertentu, yang dipilih oleh seseorang untuk mendapatkan keuntungan dari pihak lain dengan melakukan representasi yang salah. Ikatan Akuntan Indonesia (2001) menjelaskan fraud merupakan salah saji yang muncul dalam kecurangan pelaporan keuangan yakni salah saji maupun menghilangkan bukti dengan sengaja pengungkapan maupun jumlah di laporan 
keuangan guna mengecoh pengguna laporan keuangan. Salah saji yang muncul dari tindakan tidak seharusnya terhadap aset yang mengakibatkan penyajian laporan keuangan tidak sejalan Prinsip Akuntansi Berterima Umum (PABU) di Indonesia.

\section{Ketidak-sesuaian Kompensasi}

Menurut Hariandja (2005), kompensasi adalah imbalan yang diperoleh pegawai berbentuk uang maupun lainnya akibat dari kontribusi yang diberikan kepada perusahaan yang berbentuk upah, gaji, tunjangan, insentif, dan bonus lainnya yang di berikan oleh perusahaan. Hasibuan (2003) mendefinisikan kompensasi sebagai imbalan yang layak dan adil yang diterima karyawan atas kontribusi dalam menggapai sasaran instansi. Merujuk Kasmir (2002), agar kompensasi yang diberikan wajar dan adil sesuai dengan tujuan organisasi dapat tergapai, maka kompensasi harus dirancang dan dibuat mengacu pada pengalaman dan pendidikan serta beban kerja. Pemberian kompensasi yang tidak sesuai dengan jasa yang dikeluarkan pegawai dapat mengakibatkan pegawai merasa berhak melakukan berbagai upaya untuk mendapatkan pemasukan tambahan yang dirasa sesuai dengan jasa yang telah dikeluarkan pegawai, termasuk upaya untuk melakukan kecurangan dalam rangka mensejahterakan diri sendiri maupun keluarganya.

\section{Ketidak-efektifan Pengendalian Internal}

Menurut Mulyadi dan Puradiredja (1998), Sistem Pengendalian Internal merupakan upaya yang dilaksanakan untuk memberikan kepercayaan terkait capaian ketaatan kepada aturan, efisiensi kegiatan, serta kehandalan laporan keuangan. Pengendalian yang tidak efektif dalam suatu organisasi dapat memberi celah adanya niat untuk melakukan kecurangan yang dapat mengakibatkan kerugian bagi organisasi. Ketidakefektifan pengendalian internal mempermudah pegawai dalam melakukan penyimpangan-penyimpangan dalam rangka memperoleh keuntungan untuk diri sendiri, sehingga ketidak-efektifan pengendalian internal dalam suatu organisasi menjadi penting untuk diperhatikan berkaitan dengan adanya tindakan fraud dalam organisasi tersebut.

\section{Perceived Behavioral Control}

Secara spesifik perceived behavioral control didefinisikan sebagai persepsi individu mengenai kemudahan atau kesulitan untuk melakukan suatu perilaku. Perceived behavioral control ditentukan oleh kombinasi antara belief individu 
mengenai faktor pendukung dan/atau penghambat untuk melakukan suatu perilaku (control beliefs), dengan kekuatan perasaan individu akan setiap faktor pendukung ataupun penghambat tersebut.

\section{Hipotesis}

$\mathrm{H}_{1}$ : Ketidak-sesuaian kompensasi berpengaruh positif terhadap perilaku fraud.

$\mathrm{H}_{2}$ : Ketidak-efektifan pengendalian internal berpengaruh positif terhadap perilaku fraud.

$\mathrm{H}_{3}$ : Perceived behavioral control berpengaruh positif terhadap perilaku fraud.

\section{METODE PENELITIAN}

\section{Populasi dan Sampel}

Populasi dalam riset ini adalah seluruh Aparatur Sipil Negara (ASN) di lingkungan Dinas se-Kota Tegal yang berjumlah 564 ASN. Teknik pengambilan sampel dilakukan secara purposive sampling dengan tujuan untuk mendapatkan sampel yang representatif sesuai dengan kriteria yang ditentukan. Kriteria sampel riset ini adalah pejabat struktural pada masing-masing dinas di Kota Tegal yang berjumlah 155 ASN, yang seluruhnya menjadi sampel dalam riset ini. Prosedur pengumpulan data yang dipakai riset ini ialah data primer berupa kuesioner. Sebelum memulai distribusi kuesioner ke responden, terlebih dahulu dilakukan uji coba (pilot testing) terhadap instrumen riset tersebut.

\section{Teknik Analisis Data}

Metode riset dalam mengolah data riset ini menggunakan metode kuantitatif. Tabulasi data dan teknik analisis statistik yang dipakai untuk riset ini menggunakan partial least square (PLS) dengan software aplikasi SmartPLS 3.0.

\section{HASIL DAN PEMBAHASAN}

Analisis terhadap data riset dilakukan dengan program Smart PLS. Tahap pertama adalah melakukan uji outer model konstruk relatif untuk model struktural dan menganalisis parameter estimasi antar faktor. Parameter tersebut menjelaskan hubungan kausalitas antar faktor.

a) Evaluasi Nilai Loading Faktor

Dari hasil output analisis dapat dilihat bahwa semua konstruk dengan indikator refleksif menghasilkan nilai loading faktor $>0,70$.

b) Average Variance Extracted (AVE) 
Dari hasil output analisis dapat dilihat bahwa semua konstruk refleksif menghasilkan nilai average variance extracted $(\mathrm{AVE})>0,50$.

c) Composite Reliability

Nilai composite reliability yang dihasilkan semua konstruk sangat baik yaitu > 0,70 .

Pengujian inner model maupun model struktural diadakan dengan tujuan meyakinkan bahwa model struktural yang dibentuk akurat dan robust. Evaluasi inner model bisa diperoleh dari indeks koefisien determinasi $\left(\mathrm{R}^{2}\right)$ untuk model struktural. Berdasarkan hasil pengujian, 52,8\% variabel perilaku fraud dapat dijelaskan oleh variabel ketidak-sesuaian kompensasi, ketidak-efektifan pengendalian internal, dan perceived behavioral control.

Berdasarkan hasil pengujian terhadap Hipotesis 1, riset ini tidak menemukan adanya pengaruh signifikan ketidak-sesuaian kompensasi terhadap perilaku fraud. Pengujian berhasil menunjukkan adanya arah pengaruh positif, akan tetapi dengan tingkat signifikansi yang lemah. Dengan demikian, maka Hipotesis 1 ditolak. Tidak sesuainya kompensasi yang diterima oleh pegawai tidak menyebabkan meningkatnya perilaku fraud.

Berdasarkan hasil pengujian terhadap Hipotesis 2, riset ini berhasil menemukan adanya pengaruh signifikan ketidak-efektifan pengendalian internal terhadap perilaku fraud dengan arah pengaruh positif. Dengan demikian, maka Hipotesis 2 diterima. Semakin tidak efektif pengendalian internal pada suatu instansi maka akan semakin tinggi perilaku fraud pada instansi tersebut.

Berdasarkan hasil pengujian terhadap Hipotesis 3, riset ini berhasil menemukan adanya pengaruh signifikan perceived behavioral control terhadap perilaku fraud dengan arah pengaruh positif. Dengan demikian, maka Hipotesis 3 diterima. Semakin banyak faktor pendukung untuk melakukan fraud maka pegawai akan mempersepsikan diri mudah untuk melakukan fraud sehingga perilaku fraud meningkat.

\section{KESIMPULAN}

Berdasarkan hasil pengujian terhadap hipotesis yang diajukan, kesimpulan dari riset ini adalah sebagai berikut: 
1. Ketidak-sesuaian kompensasi tidak memiliki pengaruh yang signifikan terhadap perilaku fraud. Hasil ini mengindikasikan bahwa pemberian kompensasi bukan menjadi faktor pemicu timbulnya perilaku fraud pada Dinas di Kota Tegal. Tidak sesuainya kompensasi yang diberikan instansi kepada pegawai tidak menjadikan penyebab meningkatnya perilaku fraud pada instansi tersebut. Hal ini diduga karena besaran kompensasi yang diterima pegawai Dinas di Kota Tegal merata sesuai dengan jabatan masing-masing sehingga sistem kompensasi ini tidak memicu adanya kecemburuan sosial di lingkungan Dinas Kota Tegal.

2. Ketidak-efektifan pengendalian internal memiliki pengaruh positif signifikan terhadap perilaku fraud. Hasil ini mengindikasikan bahwa perilaku fraud yang terjadi di Dinas Kota Tegal dapat diminimalkan dengan pengendalian internal yang efektif, karena semakin tidak efektif pengendalian internal dalam suatu instansi akan meningkatkan perilaku fraud pada instansi tersebut. Hal ini menunjukkan bahwa secara umum pengendalian internal pada lingkungan pegawai Dinas di Kota Tegal berpengaruh kuat dalam menentukan tindakan pegawai.

3. Perceived behavioral control memiliki pengaruh positif signifikan terhadap perilaku fraud. Hasil ini mengindikasikan bahwa perilaku fraud yang terjadi di Dinas Kota Tegal dapat diminimalkan dengan perceived behavioral control yang baik, karena semakin pegawai merasakan banyak faktor pendukung untuk melakukan fraud dan sedikit faktor penghambat untuk melakukan fraud maka pegawai akan memiliki persepsi mudah untuk melakukan fraud sehingga perilaku fraud cenderung akan meningkat. Hal ini menunjukkan bahwa secara umum perceived behavioral control pada lingkungan pegawai Dinas di Kota Tegal berpengaruh kuat dalam mempengaruhi perilaku pegawai.

Penelitian ini memiliki beberapa keterbatasan yang masih dapat diperbaiki dan dikembangkan menjadi riset yang lebih baik lagi. Adapun keterbatasan penelitian ini yaitu:

1. Pengiriman kuesioner hanya ditujukan kepada pejabat eksekutif selaku perancang anggaran dan kegiatan, sementara itu pengesahan anggaran dan kegiatan merupakan wewenang pejabat legislatif. Hal tersebut mengakibatkan adanya ketimpangan, karena komposisi responden kurang seimbang. 
2. Pengambilan data juga hanya dengan menggunakan kuesioner tertutup, sehingga tidak dapat menggambarkan realita yang terjadi dilapangan.

\section{Saran}

Berdasarkan keterbatasan tersebut, maka peneliti memberikan saran berupa:

1. Pengiriman kuesioner juga ditujukan kepada pejabat legislatif yang memiliki wewenang dalam pengesahan anggaran dan kegiatan.

2. Pengambilan data tidak hanya menggunakan kuesioner tertutup, tetapi juga dengan wawancara dan lain sebagainya.

\section{DAFTAR PUSTAKA}

Adi, M.R.K., Komala A., dan Arum A. 2016. "Analisis Faktor-Faktor Penentu Kecurangan Pada Sektor Pemerintahan.” Jurnal Litbang Kota Pekalongan Vol. 10, No. 1, Hal. 1-10

Ahriati, Deni, Prayitno B, dan Erna W. 2015. “Analisis Pengaruh Sistem Pengendalian Internal, Asimetri Informasi, Perilaku Tidak Etis Dan Kesesuaian Kompensasi Terhadap Kecenderungan Kecurangan Akuntansi Pada Pemerintah Daerah Kabupaten Lombok Timur.” Jurnal InFestasi Vol. 11, No.1 Hal. 41-55

Ajzen, Icek. 1991. "The Theory of Planned Behavior." Organizational Behavior and Human Decision Processes. Vol. 50, Issue. 2, pp. 179-211.

. 2006. "Constructing a TPB Questionaire: Conceptual and Methodological Considerations." http://www.people.umass.edu/aizen/, diakses 3 April 2017.

Amrizal. 2004. "Pencegahan dan Pendeteksian Kecurangan oleh Internal Auditor." http://www.bpkp.go.id/files/PDF/cegah_deteksi, diakses 3 April 2017.

Arens, A. Alvin, Ellder J. Ronald \& Beasley Mark S. 2008. Auditing dan Jasa Assurance Pendekatan Terintegrasi. Jakarta: Erlangga.

Ariani, Ketut Sulasmi, Lucy S.M, dan Nyoman T.H. 2014. "Analisis Pengaruh Moralitas Individu, Asimetri Informasi Dan Keefektifan Sistem Pengendalian Internal Terhadap Kecenderungan Kecurangan Akuntansi Di PDAM Kab Bangli” e-Journal S1 Ak Universitas Pendidikan Ganesha. Vol 2, No. 1, Hal. 11-21.

Blanthorne, C.M. 2000. The Role of Opportunity an Beliefs on Tax Evasion: A Structural Equation Analysis. Dissertation. Arizona State University.

Bobek, Donna D., Richard C. Hatfield. 2003. "An Investigation of the Theory of Planned Behavior and The Role of Moral Obligation in Tax Compliance." Behavioral Research in Accounting. Vol. 15. Issue 1, pp. 13-38.

Chandra, Devia Prapnalia dan Sukardi Ikhsan. 2015. "Determinan Terjadinya Kecenderungan Kecurangan Akuntansi pada Dinas Pemerintah Se-Kabupaten Grobogan.” Accounting Analysis Journal. Vol. 4, No. 3, Hal.1-9. 
Cressey, Donald R. 1953. "Others People Money, A Study in The Social Psychology of Embezzlement." Montclair: Patterson Smith.

Cummings, R.G., Vazquezb, J.M., McKeec, M. dan Togler, B. 2009. “Tax Morale Affects Tax Compliance: Evidence from Surveys and An Artefactual Field Experiment." Journal of Economic Behavior \& Organization. Vol. 70. Issue 1, pp. 447-457.

Davis, F.D. 1989. "Perceived Usefulness, Perceived Ease of Use and User Acceptance of Information Technology.” MIS Quarterly. Vol. 13, No. 3, pp. 319-339.

Ghozali, Imam. 2011. Aplikasi Analisis Multivariate dengan Program IBM SPSS 19. $5^{\text {th }}$ Ed. Semarang: Badan Penerbit Universitas Diponegoro.

Ghozali, Imam. 2014. Structural Equation Modeling Metode Alternatif Dengan Partial Least Squares (PLS). $4^{\text {th }}$ Ed. Semarang: Badan Penerbit Universitas Diponegoro.

Ghozali, Imam dan Hengky Latan. 2015. Partial Least Squares. Konsep, Teknik dan Aplikasi Menggunakan Program SmartPLS 3.0 Untuk Penelitian Empiris. $2^{\text {nd }}$ Ed. Semarang: Badan Penerbit Universitas Diponegoro.

Hariandja, Marihot T. Efendi. 2005. Manajemen Sumber Daya Manusia. Jakarta: Grasindo.

Hasibuan, Malayu. 2003. Manajemen Sumber Daya Manusia. Jakarta: Bumi Aksara.

Hidayat, Widi dan Nugroho, Argo Adhi. 2010. "Studi Empiris Theory of Planned Behavior dan Pengaruh Kewajiban Moral pada Perilaku Ketidakpatuhan Pajak Wajib Pajak Orang Pribadi.” Jurnal Akuntansi dan Keuangan, Vol. 12, No. 2, Hal. 82-93.

Ikatan Akuntansi Indonesia. 2001. Standar Profesional Akuntansi Publik. Jakarta: Salemba Empat

Indriastuti, D.E., Agusdin, dan Animah. 2016. "Analisis Pengaruh Asimetri Informasi, Pengendalian Internal, Persepsi Kesesuaian Kompensasi, Moralitas Individu, Dan Ketaatan Aturan Akuntansi Terhadap Kecenderungan Fraud Pemkab Lombok Tengah.” Jurnal InFestasi Vol. 12 No.2 Hal. 115-130.

Jogiyanto, H.M. 2007. Sistem Informasi Keperilakuan. Yogyakarta: Andi Offset

Kadarisman. 2012. Manajemen Kompensasi. Jakarta: Raja Grafindo Persada.

Kasmir. 2002. Manajemen Perbankan. Jakarta: Raja Grafindo Persada.

Luthans, F. 1998. Organizational Behavior $8^{\text {th }}$ ed. Boston: Irwin McGraw-Hill.

Mulyadi dan Puradiredja, K. 1998. Auditing. $5^{\text {th }}$ Ed. Jakarta: Salemba Empat.

Mulyadi. 2009. Auditing. Buku 1, Edisi 6. Jakarta: Salemba Empat.

Mustika, Dian, Sri Haastuti, dan Sucahyo Heriningsih. 2016. "Analisis Faktor-Faktor Yang Mempengaruhi Kecenderungan Kecurangan Way Kanan Lampung" Simposium Nasional Akuntansi XIX, Hal. 1-22. 
Najahningmrum, Anik Fatun. 2013. "Faktor-Faktor yang Mempengaruhi Kecenderungan Kecurangan (Fraud): Persepsi Pegawai Dinas Provinsi DIY. Accounting Analysiz Journal Vol.2, No. 2, Hal. 25-40.

Omar, Normah, Razana J.J., Siti S.B.S, and Jamaliah S. 2015. "Money Laundering and Terrorist Financing: Real Global Cases, Behavioural Theories and Internal Control Mechanism" Springer Proceding in Bussines and Economics

Peraturan Pemerintah Nomor 24 tahun 2005 tentang Standar Akuntansi Pemerintahan.

Peraturan Pemerintah Nomor 58 Tahun 2005 tentang Pengelolaan Keuangan Daerah.

Peraturan Pemerintah Nomor 60 Tahun 2008 tentang Sistem Pengendalian Intern Pemerintah.

Prawira, I Made D., Nyoman T.H., Nyoman A.S.D. 2014. "Pengaruh Moralitas Individu, Asimetri Informasi Dan Efektivitas Pengendalian Internal Terhadap Kecenderungan Kecurangan (Fraud) Akuntansi BUMD Buleleng”. e-Journal S1 Ak Universitas Pendidikan Ganesha. Vol 2, No. 1, Hal.1-12.

Putri, Ananda A.P.A. 2014. "Pengaruh Keefektifan Pengendalian Internal Dan Kepuasan Kerja Terhadap Kecenderungan Kecurangan Akuntansi Pada DPPKA DIY" Jurnal Nominal Vol. III, No. 1, Hal. 61-74.

Rae, Kristi and Nava Subramaniam. 2008. "Quality Of Internal Control Procedures, Antecedents And Moderating Effect On Organisational Justice And Employee Fraud." Emerald Insight Journal.

Rahmawati. 2014. Teori Akuntansi Keuangan. Yogyakarta: Graha Ilmu.

Rivai, Veithzal. 2011. Manajemen Sumber Daya Manusia Untuk Perusahaan. Jakarta: PT. Rajagrafindo Persada.

Sekaran, Uma. 2014. Research Methods for Business, Metodologi Penelitian untuk Bisnis. Buku 2, Edisi 4. Jakarta: Salemba Empat.

Shintadevi, Prekanida Farizqa. 2015. "Pengaruh Keefektifan Pengendalian Internal, Ketaatan Aturan Akuntansi dan Kesesuaian Kompensasi terhadap Kecenderungan Kecurangan Akuntansi dengan Perilaku Tidak Etis sebagai Variabel Intervening.” Jurnal Nominal. Vol. 4, No. 2, Hal.111-126.

Taylor S., Todd, P.A. 1995. "Understanding Information Technology Usage: A Test of A Competing Models." Information System Research. Vol. 6, No. 4, pp. 144-176.

Tuanakotta, Theodorus M. 2014. Audit Forensik dan Audit Investigatif. Jakarta: Fakultas Ekonomi Universitas Indonesia.

Undang-Undang Nomor 32 tahun 2004 tentang Pemerintahan Daerah.

Virmayani, Putu C., Ni Luh Gede E.S. dan Anantawikrama T.A. 2017. "Pengaruh Kesesuaian Kompensasi, Asimetri Informasi, Budaya Etis Organisasi dan Komitmen Organisasi terhadap Kecenderungan Kecurangan (Fraud) Akuntansi pada Koperasi Simpan Pinjam Se-Kecamatan Buleleng.” e-Journal S1 Ak Universitas Pendidikan Ganesha. Vol. 7, No. 1, Hal. 1-12. 
Wilopo. 2006. "Analisis Faktor-Faktor Yang Berpengaruh Terhadap Kecenderungan Kecurangan Akuntansi." Simposium Nasional Akuntansi IX Padang

Zimbelman, Mark F. et al. 2014. Akuntansi Forensik. Jakarta: Salemba Empat 